\title{
Could Nationalism Sense be Reached Through Cultural Tourism Activity?
}

\author{
Purwanti Dyah Pramanik, Rahmat Ingkadijaya, Devita Gantina \\ Sekolah Tinggi Pariwisata Trisakti \\ Jakarta, Indonesia \\ purwanti@stptrisakti.ac.id
}

\begin{abstract}
Cultural tourism activity could be one of the educational choices to reach emotional well-being. In the point of consumers' view, one of the emotional well-being is having a sense of nation of ones country. It is similar with nasionalism sense. By having experience in a certain local tourism, watching traditional dance performances or informing and tasting a wide range of traditional food, people is going to be more familiar with their own culture, more fond of their own culture, and more proud of their own culture. This research aimed to analyze the respondents' nasionalism sense after having cultural tourism activity by visiting Tekstil Jakarta Museum and Rumah Budaya Nusantara Puspo Budoyo (RBNPB) in Tangerang Selatan. The respondents are 74 of the new students' parent of Trisakti School of Tourism who are traveling together to visit Tekstil Jakarta Museum and RBNPB. The study made use of descriptive research design. The sample are choosen by simple random sampling. The data are collected by distributing questionaires. The analysis includes validity and reliability, frequency, and descriptive. The study found that after having tourism services by visiting Tekstil Jakarta museum and RBNPB, the respondents were more familiar with their own culture, more fond of their own culture, and more proud of their own culture.
\end{abstract}

Keywords - nasionalism sense, cultural tourism activity

\section{INTRODUCTION}

Globalization influences nasionalism sense (Elena, 2015). The impact could be postivive and negative. The positive impact could result such as having global vision in developing local advantages. It can be said the same with the statement "think globally; act locally" for promoting local culture through social media. Another example of the positive one is making standardization for local culinaries. The example of negative effects are imitating imported culture without any consideration. Those are wearing torn jeans or eating junk food.

Currently, people's nationalism sense is going to decrease. Firstly, it is identified by the lack of knowledge of their culture. They aren't familiar with their own traditional dances or traditional food. Secondly, people prefer to travel abroad instead of visiting local tourist destination. Thirdly, people would rather to choose non-traditional food such as Japanese or Korean Food. This condition is caused by many aspects. Firstly, they don't realize that Indonesia has a lot of amazing tourist destination, traditional dances, and traditional food. Secondly, there is the lack of local culture promotion. Local culture must be introduced to community seriously. In this case Korea is a good example in promotion. Korea introduces their culture by a movie. By watching its film, audiences are introduced to a variety of Korean culinary as well.

Indonesia is a multicultural nation. It consists of around 1.128 ethnics from Sabang to Merauke, such as Aceh, Batak, Sunda, Java, Toraja, Minahasa, Ambon and many more. There are also six religions that are existed in Indonesia. They are Islam, Christian, Catholic, Hindu, Buddhist, and Confucian. The more variety of differences, there will be the more disunity. Based on those facts, it is very important to discuss of nationalism. Ingkadijaya et al (2016) studied of the contribution of tourism on family cohesion. The research showed that traveling activity was able to maintain and improve family cohesion. The tourism researchs that had been done focus of economics point of view. It analyzed local area income or job opportunities. Actually, the tourism research can discuss in the point of tourists view. This research aimed to analyze if cultural tourism activities influent a sense of nationalism.

\section{Nationalism}

Nationalism is defined as an exclusive value of someone national identity where he/ she is going to isolate him/herself to a certain nation (Bujorean, 2015). National identity is an emotional attachment of a national community (Lau, Lam, \& Leung, 2008). This emotional attachment can be reached through tourism educational choices. By giving experiences in tourism activity, people is going to be more (1) familiar with their culture, (2) fond of their culture, and (3) proud of their culture (Damanik, 2012).

\section{Cultural Tourism Activity}

Tourism has a strong impact to human development (Pyke, Hartwell, Blake, \& Hemingway, 2016). It can influence many aspects. They are the relationship with family and friends, emotional well-being, material well-being, health and personal safety, work and production, and local community. This study focused on its impact of emotional well-being. Emotional well-being is the feelings of pleasure, agitation, and dominance (Galina \& Irina, 2014). One of its feelings is its 
pleasure, agitation, and dominance of national traditions or in another word nasionalism sense.

There are a wide range of cultural tourist activities. They are enjoying (traditional) culinary tourism, watching cultural festival and cultural ceremony or visiting historical place and museum. Participating in (traditional) culinary tourism and visiting museum has high satisfaction indeks of tourist. Satisfaction index of attending culinary torism is 88.3 while satisfaction index of enjoying museum is 74.2 (Ingkadijaya, 2016).

\section{Tourism and nationalism}

Nationalism sense can be reached through tourism. Tourism activities development based on cultural heritage can enhance cultural identity awareness and regional pride (Vana \& Malaescu, 2015). Moreover, cultural heritage tourism is effective to decrease conlict among social group (Vana \& Malaescu, 2015). By having identity a nation will feel secure (Botterill, 2016).

A sense of nationalism can be developed through tourism education (Pyke, Hartwell, Blake, \& Hemingway,2016). Tourism education is one of tourism services (Khasanov, 2015). This service aims to educate community to reach emotional well-being. Educating people of tourism can be done by traveling in group to visit museum, enjoying traditional dance performances, or learning how to cook traditional food. The group can be a small group such as a family which consists of parents and their children. But there can be a bigger group such as a group of students and their teachers or a group student's parents.

There are many tourist activities that are enhancing a sense of nasionalism. Some of them are visiting Tekstil Jakarta Museum and Rumah Budaya Nusantara Puspo Budoyo (RBNPB).

Tekstil Jakarta museum is a cultural museum. It displays a wide range of Indonesia traditional woven, especilally batik. There are batik from Betawi, West Java, Central Java, and East Java. The museum also facilitates visitors to practice how to create batik.

Tekstil Jakarta museum was established in 1976 in the era of Ali Sadikin Governor. The vision of building the museum is for being "non-profit institution to be the centre of culture, scientific activitiy media, art and culture, education, the center of information and educational cultural recreation, which are able to be reference for the nation development." It's managed by Jakarta local government. This museum is located on jalan Aipda KS Tubun No.2-4, Jakarta Pusat.

RBNPB is a cultural centre. It's established on August 6.2003 by Mr. H. Luluk Sumiarso. This cultural centre is for sustaining local culture which is going to decrease from time to time. The activities in this centre are vary, such as dance performances, musical performances, or traditional puppet performances. RBNPB is located on jalan Elang Raya, Kampung Sawah, Ciputat, Tangerang Selatan, Banten.

Based on the background above, this research aimed to analyze the respondents' nasionalism sense after having tourism services. Tourism services consist of visiting Tekstil
Jakarta Textile museum, enjoying traditional dance performances, and learning how to cook traditional recipes at RBNPB. Participating in culinary tourism and visiting museum has high satisfaction indeks of tourist. Satisfaction index of attending culinary tourism is 88.3 while satisfaction index of enjoying museum is 74.2 (Ingkadijaya, 2015). The frame of research as identified at Fig.1.

\begin{tabular}{|c|c|}
\hline $\begin{array}{l}\text { Tourism services: After } \\
\text { 1. visiting museum. } \\
\text { 2. enjoying traditional } \\
\text { dance performances. } \\
\text { 3. learning how to cook } \\
\text { traditional recipes. }\end{array}$ & $\begin{array}{l}\text { Nasionalism sense: } \\
\text { Respondents are more } \\
\text { 1. familiar with their } \\
\text { culture. } \\
\text { 2. fond of their culture. } \\
\text { 3. proud of their culture. }\end{array}$ \\
\hline
\end{tabular}

Fig. 1. Tourism services and nasionalism sense

(Source: Adopted from Pyke et al., 2016)

\section{METHOD}

The study made use of descriptive research design. Object's analysis was the new students' parent of Trisakti School of Tourism who are traveling together to visit Tekstil Jakarta museum and RBNPB in Tangerang Selatan. Population was new students' parent in the year of 2015-2016 of Trisakti School of Tourism. The sample are choosen by convenience sampling. The data are collected by distributing questionaires of 74 the new students's parent of Trisakti School of Tourism. They consist of respondent's profile and three statements of respondent's sense of nationalism by using Likert Scale from 1 (strongly disagre) to 3 (strongly agree). The analysis includes validity and reliability, frequency, and descriptive.

\section{RESULT}

\section{Validity and reliability test}

The study asked three statements "(1) after having tourism services the respondents are more familiar with their culture; (2) after having tourism services, the respondents are more fond of their culture; and (3) after having tourism services the respondents are more proud of their culture. By using $r$ table in significantly .01 level (2-tailed), the number of respondents 74 $\mathrm{n}=72$ or $\mathrm{df}=\mathrm{n}-2=72$, it could be counted $\mathrm{r}$ table .2977 . Total score Pearson Correlation of the three statements are between.626 to 1 or $>.2977$. It meant that all those statements were valid.

The reliability analysis found that the three statements had Cronbach's Alpha .883 (>.80). It meant that the three statements were reliable.

\section{Frequency analysis}

Table 1 describes the frequency analysis. First of all, according to the gender, 16 persons are male ( 21.6 percent $)$ and 58 people are female (78.4 percent). It can be understood because this event is for parents of students. That's why most of the respondents who attend the traveling are the student's mothers. 
TABLE I. FREQUENCY ANALYSIS

\begin{tabular}{|c|c|c|c|}
\hline \multirow{3}{*}{$\begin{array}{l}\text { Respondent } \\
\text { Gender }\end{array}$} & \multirow[t]{2}{*}{ Profiles } & \multicolumn{2}{|c|}{$\begin{array}{l}\text { The percentage of persons who visit museum, enjoy traditional } \\
\text { dance performances, \& lean how to cook traditional recipes }\end{array}$} \\
\hline & & $21.6 \%$ & \\
\hline & Female & $78.4 \%$ & \\
\hline \multirow[t]{3}{*}{ Age } & $18-36$ years old & $5.4 \%$ & \\
\hline & $37-55$ years old & $87.8 \%$ & \\
\hline & Above 55 years old & $6.8 \%$ & \\
\hline \multirow[t]{5}{*}{ Job } & Private employee & $31.1 \%$ & \\
\hline & Civil servant & $8.1 \%$ & \\
\hline & Entrepreneur & $16.2 \%$ & \\
\hline & Housewife & $43.2 \%$ & \\
\hline & Others & $1.4 \%$ & \\
\hline \multirow[t]{4}{*}{ Education } & Senior High School & $50 \%$ & \\
\hline & Vocational College & $20.3 \%$ & \\
\hline & Undergraduate & $27 \%$ & \\
\hline & S2 & $2,7 \%$ & \\
\hline \multirow[t]{5}{*}{ Salary (IDR) } & Less than 5 million & $39 \%$ & \\
\hline & $5-<10$ million & $34 \%$ & \\
\hline & $10-<15$ million & $17.6 \%$ & \\
\hline & $15-<20$ million & $5.4 \%$ & \\
\hline & Above 20 million & $4 \%$ & \\
\hline \multicolumn{2}{|c|}{ Respondents' perception } & Agree & Strongly agree \\
\hline \multicolumn{4}{|c|}{$\begin{array}{l}\text { After visiting museum, enjoying traditional } \\
\text { performance dances, and learning how to cook } \\
\text { traditional recipes, respondents are more: }\end{array}$} \\
\hline \multicolumn{2}{|c|}{ Familiar with your culture } & $13.5 \%$ & $86.5 \%$ \\
\hline \multicolumn{2}{|c|}{ Fond of your culture } & $13.5 \%$ & $86.5 \%$ \\
\hline \multicolumn{2}{|c|}{ Proud of your culture } & $10.8 \%$ & $89.2 \%$ \\
\hline
\end{tabular}

The second, based on the age are dominated by the people of 37 to 55 years old. It is 65 people or 87.8 percent. The respondents at the age of 18 to 36 years old are the least. It is only 4 persons or 5.4 percent. And the respondents at the age of above 55 years old are 5 persons or 6.8 percent. The respondents are the parents of college students who are average 18 years old. So that, the age of the respondents must be between 37 to 55 years old.

TABLE II. THE IMPACT OF CULTURAL ACTIVITIES ON NATIONALISM SENSE

\begin{tabular}{llll}
\hline \multicolumn{1}{c}{ Nationalism } & Visit museum & $\begin{array}{c}\text { Enjoy dance } \\
\text { performances }\end{array}$ & $\begin{array}{c}\text { Learning how to } \\
\text { cook traditional } \\
\text { recipes }\end{array}$ \\
\hline $\begin{array}{l}\text { More familiar } \\
\text { with their }\end{array}$ & 2.86 & 2.86 & 2.86 \\
$\begin{array}{l}\text { culture } \\
\text { More fond of } \\
\text { their culture }\end{array}$ & 2.86 & 2.86 & 2.86 \\
$\begin{array}{l}\text { More proud } \\
\text { of } 2.89\end{array}$ \\
culture their
\end{tabular}

The third, the research studied the job of the respondents. The respondents include 23 persons of private employees (31.1 percent), 6 persons of civil servants ( 8.1 percent), 12 persons of entrepreneur (16.2 percent), 32 persons of housewives (43.2 percent), and 1 person of other (1.4\%). The respondents are dominated by housewives; it is related to the condition that most of the respondents are female or the mothers of the students.
The fourth, the study learned that most of the respondents' educational background is senior high school (37 people or 50 percent). The respondents who are graduated from vocational school are 15 persons or 20.3 percent. There are 20 persons or 27.0 percent who has undergraduate background. And 2 persons or 2.7 percent respondents graduated from S2 program.

Finally, according to the salary 29 persons or 39 percent has salary less than 5 million rupiahs, 25 persons or 34 percent has salary from 5 to less than 10 million rupiahs, 13 persons or 17.6 percent has salary from 10 to less than 15 million rupiahs, 4 persons or 5.4 percent has salary from 15 to less than 20 million rupiahs, and only 3 persons or 4 percent has salary more than 20 million rupiahs. The amount of the salary is dominated by people who have less than 5 million rupiahs, because most the respondents are housewives. They don't have their own salary. In other words they only got less than 5 million rupiahs from their husband.

The research found that after having tourism services 10 people or 13.5 percent agreed that they were more familiar with their culture. Then the study also found that after having tourism services 64 people or 86.5 percent strongly agreed that they were more familiar with their culture.

Secondly, the study found that after having tourism services 10 respondents or 13.5 percent agreed that they were more fond of their culture, and 64 respondents or 86.5 percent strongly agreed that they were fond of their culture.

The study also found that 8 persons or 10.8 percent agreed that after having tourism services they were more proud of their culture. Moreover 66 people or 89.2 percent of 
respondents were strongly agreed that after having tourism services, they were more proud of their culture.

\section{Descriptive analysis}

According to table 2 and table 3 there could be explained that the study found: (1) the statement of "after having tourism services I am more familiar with our culture" got the mean 2.86. It meant the respondents strongly agree that after having tourism services they were more familiar with their own culture.

TABLE III. RESPONDENTS' NASIONALISME SENSE AFTER TRAVELING

\begin{tabular}{lc}
\hline \multicolumn{1}{c}{ After traveling respondents are: } & Mean \\
\hline More familiar with their culture & 2.86 \\
More fond of their culture & 2.86 \\
More proud of their culture & 2.89 \\
\hline
\end{tabular}

The number of respondents on each statement are 74. By using the patern below:

$$
\mathrm{L}=\frac{\mathrm{k}(\mathrm{n}+1)}{\mathrm{n}}
$$

Note:

$\mathrm{K}=$ the position of....

$\mathrm{N}=$ the number of data or Likert Scale

The interval scores are as follow in table IV.

TABLE IV. INTERVAL SCORES OF MEAN

\begin{tabular}{ll}
\hline \multicolumn{1}{c}{ Interval score } & \multicolumn{1}{c}{ Remarks } \\
\hline $1.0-1.01$ & Strongly disagree \\
$1.02-2.03$ & Agree \\
$2.04-3.04$ & Strongly agree \\
\hline
\end{tabular}

(2) The statement of "after having tourism services I am more fond of our culture" got the mean 2.86. It meant the respondents strongly agree that after traveling they were more fond of their own culture; and (3) the statement of "after having tourism services I am more proud of our culture" got the mean 2.89. It meant the respondents strongly agreed that after traveling they were more proud of their own culture. Those had the same result for each activity partially and for the total of the three activities.

\section{CONCLUSION}

The study found that after having tourism services, the respondents' sense of nationalism was improved. In this research, this meant that after visiting Tekstil Jakarta museum, enjoying traditional dance performances, and learning how to cook traditional recipes, the respondents are more familiar with their own culture, more fond of their own culture, and more proud of their own culture as well.

Based on the research result, the idea of travelling together in group such as "darmawisata" to visit local cultural destination will be good to be implemented.

\section{REFERENCES}

Botterill,K., Hopkins, P., Sanghera, G., \& Arshad, R.(2016). Securing disunion: Young People's nationalism, identities and (in) securities in the campaign for an independent Scotland. Journal Political Geography, 55, 124.

Bujorean, E. (2015). The Discourse of Majority in Romanian Textbooks: Nationalism versus Europeanism. Jurnal Procedia of Social and Behavioral Sciences, 180, 503.

Damanik, P.J. (2012). Kegiatan Wisata dan Rekreasi Keluarga sebagai Sarana Pendidikan Cinta Tanah Air. Yogyakarta, Gajah Mada University.

Galina, B. (2015). Improving the Socio-emotional Well-being of the Older Generation through the Implementation of Territorial Marketing. Journal Procedia Social and Behavioral Sciences, 166, 63.

Ingkadijaya, R. (2015). Motif, Aktivitas, Kepuasan Berwisata, dan Kontribusinya pada Kepaduan Keluarga. Disertation. Yogyakarta, Gajah Mada University.

Ingkadijaya, R., Damanik, J., Putra, H.S.A., Nopirin. (2015). Tourist activities contribution on family cohesion. In Heritage, Culture and Society: Research agenda and best practices in the hospitality and tourism industry (eds. Radzi, S.M., et al.). London, CRC Press, Taylor \& Francis Group.

Khasanov, I.Sh. (2015). Research Methodology of the Tourism and Hospitality Sector in Republic Tatarstan as Transaction Type of Economic Activity. Journal Procedia Economics and Finance, 24, 313.

Lau, P.W.C., Lam, M.H.S., \& Leung, B.W.C (2010). National Identity and the Beijing Olympics: School Children's Responses in Mainland China, Taiwan \& Hongkong. Journal Procedia Social and Behavioral Sciences, 2(5), 6730.

Pyke, S. (2016). Exploring Well-being as a Tourism Product Resource. Jurnal Tourism Management, (55), 95. 